\title{
INEFFECTIVE PUBLIC PARTICIPATION FOR EIA: THE CAUSE OF ENVIRONMENTAL ISSUES IN MALAYSIA?
}

\author{
Maisarah Makmor, Hafez Salleh, Nikmatul Adha Nordin \\ Faculty of Built Environment, University of Malaya, 50603 Kuala Lumpur, Malaysia \\ E-mail: *mysara_makmor@yahoo.com,hafez@um.edu.my,nikmatul@um.edu.my
}

\begin{abstract}
Environmental Impact Assessment (EIA) foster communication between participators to yield a more environmentally sound decision for a proposed development. Public participation is an integral element in EIA to ensure a successful EIA. Effective public participation encourages community empowerment, fair and democratic decisions and reduce thus avoid public confrontation and delay. Effective public participation is one of the key pillars to achieve effective EIA. Environmental issues are known to be the negative outcome of a poorly implemented EIA process. This paper discusses seven environmental cases that were produced from ineffective application of EIA such as Bakun Dam, Murum Dam, Baram Dam, bauxite mining in Kuantan, gold mining in Bukit Koman, sturgeon farming in Kuala Tahan and Lynas plant. The seven cases focused on the lack of public participation in the administration of EIA. Public objections and protests were results of ineffective public participations and ineffective EIAs in the chosen cases. Four out of seven cases have made substantive results where the projects stopped or ceased due to the public objections. Meanwhile, the three cases went on till today. Therefore, these cases has shown that public participation in EIA is a valuable tool which encourages transparent decision-making process and defies corrupted influences. This paper represents a section of the literature review in a research on improving the practice of public participation for EIA in Malaysia. This research develops on a framework that comprises of the inadequacies of legislation and requirements of public participation for EIA, the barriers of public participation for EIA and the recommendations to further ameliorate the barriers of public participation for EIA in Malaysia. Mixed methods research were conducted utilising questionnaire surveys and semi-structured interviews. The framework is expected to improve the practice of public participation for EIA in Malaysia holistically which covers the First and Second schedule activities.
\end{abstract}

Keywords : Public Participation; Environmental Impact Assessment (EIA); Environmental Issues; Effective Public Participation; Effective EIA

\section{INTRODUCTION}

Environmental Impact Assessment (EIA) is a legislative and comprehensive procedure that aims for an environmentally sound and sustainable development (Bhatt \& Khanal, 2009; Coşkun \& Turker, 2011; Erikstad et al., 2008; Gillespie, 2008; Lee \& George, 2000; Phillips, 2011). EIA is a pre-decision tool that facilitates interaction between participators throughout the entire process while enhancing positive impacts and ensuring environmental protection against adverse impacts of a proposed development (Bastmeijer \& Koivurova, 2008; Glasson et al., 2005; Peche \& Rodríguez, 2009; Phillips, 2011). EIA aims to assess and evaluate identified adverse impacts from a proposed development towards the environment thus improve the quality of decision making for the proposed development (Bataneih, 2007; He et al., 2009; Tigawuve, 2012; Wood, 2000). Furthermore, EIA is also known to serve a long term function by identifying, preventing and reducing serious repercussion of a proposed development towards the environment (Kolhoff et al., 2013). Kolhoff et al. (2013) also added that EIA is also utilised as an informed and participatory decision making tool whereby public participation is embedded in the EIA process. The element of public participation embedded in the EIA process is to inform and include the community in decision making for the proposed development (Kolhoff et al., 2013). Lee and George (2000) regarded that EIA is a multi-step and interdisciplinary process that aids the proposed development by determining and mitigating consequences that helps to minimize the chances of loss or delay beforehand. 
Achieving effective EIA is the primary goal of an EIA application in a country's legal system. In the context of EIA, the term effective is interpreted where the EIA process results to better decisions that guide the environmental objectives to be realised (Sadler, 1996). Bataneih (2007), Briffet (1999), Pölönen et al. (2011) and Stærdahl et al. (2004) have concluded that effective EIA can be appraised when the primary objectives of the EIA process are achieved after the application of EIA in a development. The primary objectives discussed in this context refer to minimizing the adverse impact of a development, reducing time and cost of a development and providing mitigation measures in the early stages of the development.

\section{EFFECTIVE PUBLIC PARTICIPATION FOR EIA}

A concord on public participation as a fundamental element of EIA was stated in multiple anticipated research which indicated that an EIA is not an EIA without public participation (Abaza et al., 2004; Glucker et al., 2013; Hartley \& Wood, 2005; Salomons \& Hoberg, 2014). It is also highlighted that public participation is vital to effective EIA and not only a purpose by itself (Bruch et al., 2007; Glucker et al., 2013; Salomons \& Hoberg, 2014). Therefore, effective public participation is crucial to produce the success of an EIA implementation.

Referring to Dian and Abdullah (2013), effective public participation results to community empowerment by allowing transparent communication between entities, inculcate responsibilities of governing bodies towards the community and including the community in decision-making process by the decision makers. It is imperative to have effective public participation as it has been widely discussed by multiple authors. Firstly, effective public participation yields heightened compliance to standards and generates legitimacy by emphasizing on the negative social economic impacts of policies towards the environment (Alam, 2014; Hasan et al., 2018; Lawrence, 2003; Morrison-Saunders \& Early, 2008).

Secondly, Alam (2014) stated that effective public participation renders better decisions that fulfil people's needs which are valid and will last for a longer period of time. Utilising effective public participation, it enables the stakeholders to positively influence the decisions in the development (Glucker et al., 2013; Hartley \& Wood, 2005; Hasan et al., 2018). Additionally, this will foster fair and democratic decisions that values the opinion and views of the community (Alam, 2014; Kanniah, 2000; Maidin, 2011). The inclusion of public's inputs in the decision-making process also promotes equitable and informed choice which are more socially acceptable (Abaza et al., 2004). Kanniah (2000) and Maidin (2011) also added that effective public participation encourages transparent decision-making process that defies corrupted influences.

Aiyeola et al. (2014) highlights that public participation is important to establish integration and involvement between stakeholders and the community, thus providing opportunities for constructive debates on environmental issues. Moreover, effective public participation helps in eliminating the environmental and social information gap between the stakeholders and the community (Hasan et al., 2018; Momtaz \& Gladstone, 2008; Morrison-Saunders \& Early, 2008). In consequence, decision-makers will be fully informed on any potential impacts of the decision with the local knowledge and values provided by integrating effective public participation (Morrison-Saunders $\&$ Early, 2008).

Next, effective public participation not only renders positive impacts towards the EIA process, it coincidentally helps in reducing or avoiding public controversy, confrontation and delay (Ahmad et al., 2013). Besides informing and educating the public on details of the development, public participation creates channels for an open, two-way communication that is proven to avoid confrontations and resolute conflicts (Hasan et al., 2018; Lawrence, 2003; Morrison-Saunders \& Early, 2008). Additionally, public participation promotes procedural democracy and foster better acceptance of the decision made in the EIA process (Marara et al., 2011; Nadeem \& Hameed, 2008). Conclusively, effective public participation in EIA generates positive impacts that evidently boost the quality of environment and ameliorate the quality of life (Alam, 2014). 


\section{ENVIRONMENTAL ISSUES IN MALAYSIA}

Environmental issues are known to be the negative outcome of a poorly implemented EIA process. One of the main contributors to an ineffective EIA is ineffective public participation. Evidences of ineffective application of EIA can be seen in a series of cases that resulted to environmental issues due to the lack of public participation for both First Schedule and Second Schedule activities. Poor public participation for EIA may result to public protests and confrontations as seen in past cases. This paper compiles seven cases that dated back to the 1980s which occurred in several states in Malaysia.

\subsection{The Bakun Dam}

One infamous case that is frequently being highlighted in the topic of public participation is the Bakun Dam case. Bakun Dam is the second-largest hydroelectric dam project in Asia and the most expensive energy project in Southeast Asia (Lee et al., 2014; Sovacool \& Bulan, 2011). According to Swain \& Chee (2004), the Bakun Dam is estimated to produce 2400 megawatt of hydropower and would cost the Government of Malaysia RM13.5 billion which is equivalent to 3.6 billion USD. Furthermore, Sovacool \& Bulan (2011) and Swain \& Chee (2004) regarded that the dam development contains a 210 metre high concrete dam which includes a reservoir area of $14,758 \mathrm{sq}$ kilometres which floods approximately 69,640 hectares of primary rainforest in Sarawak which is equivalent to the size of Singapore.

The Bakun Dam proposal was suggested in 1986, it was then approved, cancelled and postponed for several times and finally completed in 2011 (Fonds, 2012; Sovacool \& Bulan, 2011; Swain \& Chee, 2004). The Bakun Dam is a highly controversial case in Malaysia due to the environmental conflicts with the worldwide NGOs and the native people's objections on environmental destructions (Khalid, 2007). Sovacool \& Bulan (2011) stated that Ekran Berhad (the company in charge of the dam project) have conducted and published a number of EIAs which were administered after the construction of the dam has started.

Nevertheless, the planning of Bakun Dam is criticised for the lack of public participation and for the EIA reports which have been classified as confidential document under the Official Secret Act (OSA), thus, the EIA reports were not available for public viewing (Allison, 2000; Lee et al., 2014; Swain \& Chee, 2004). Few authors indicated that the displaced communities were never properly informed on the planning of the Bakun Dam and its consequences, nor being approached to be involved in the planning of the dam and the resettlement site (Fonds, 2012; Siciliano et al., 2018; Yong, 2011). The relocation of more than 10,000 indigenous people who are affected by the Bakun Dam were never adequately represented and deprived of their rights (Swain \& Chee, 2004). Yong (2011) added that the decisions on the relocation plans were forced to the affected communities which is a breach to the principle of free, prior and informed consent. Figure 1 show the aerial view of the Bakun Dam in Sarawak

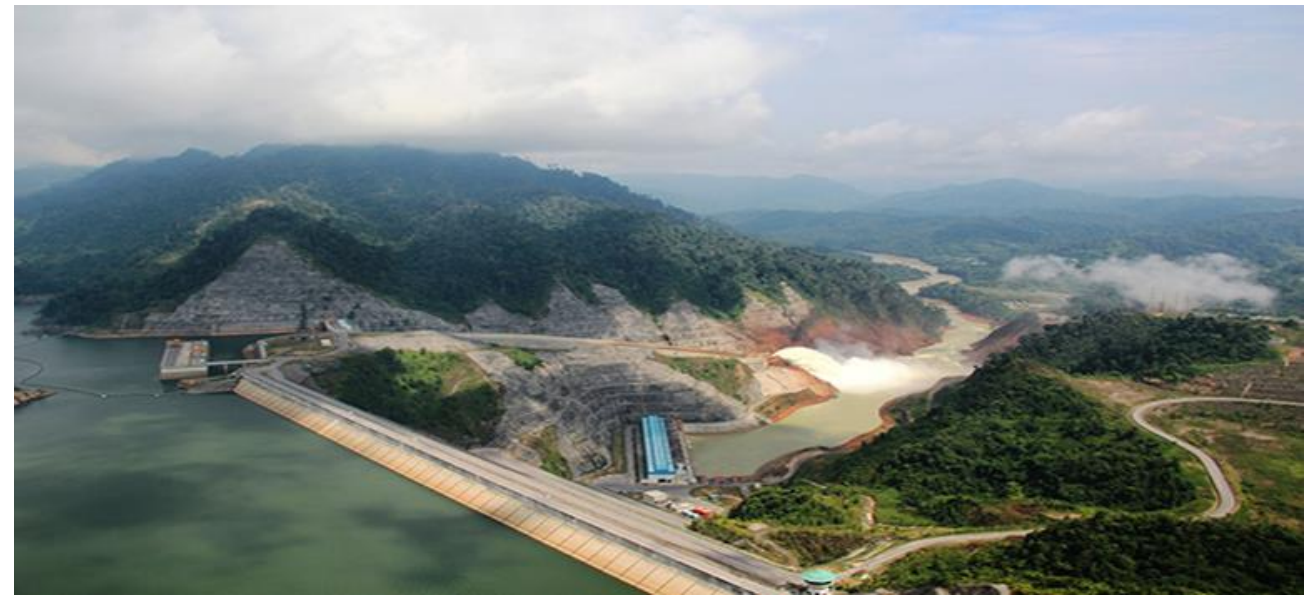

Figure 1: The Bakun Dam

Source: Achoi, J. (2017). Electricity from Bakun Dam will not be sold to Peninsular Malaysia-CM. https://www.theborneopost.com/2017/09/21/electricity-from-bakun-dam-will-not-be-sold-to-peninsular-malaysia$\mathrm{cm} /$ 


\subsection{The Murum Dam}

The Murum Dam was the next project after the Bakun Dam which starts in 2008 and had a similar issue as the Bakun Dam where the EIA for the project was administered after the construction of the dam has started (Fonds, 2012; Herbertson, 2012; Yoon, 2013). The 944 megawatt Murum Dam is the first in a series of 12 dams to be built by 2020 by the Sarawak Government under the 'Sarawak Corridor of Renewable Energy' (SCORE) (Adler, 2012; Herbertson, 2012). According to Adler (2012), lack of participation and transparency for the Murum Dam project as the information of Murum Dam was controlled by the Government.

In 2012, a blockade was made by the indigenous villagers in Sarawak caused by the circulation of a leaked copy of the government's resettlement plan among the affected villages (Herbertson, 2012). Figure 2 show the indigenous blockade made for the Murum Dam. The blockade had caused a stop in the construction of Murum Dam for over a month. Herbertson (2012) stated that the blockade has gained media attention causing the Government to conduct resettlement negotiations. Adler (2012) and Fonds (2012) stated that there was also a shortfall in the extent of free, prior and informed consultation with the affected communities where no input from the indigenous people on the planning of the dam and the resettlement process. Herbertson (2012) and Adler (2012) also regarded that the EIA report for the Murum Dam was never made public although the construction has begun few years back. As a result, the affected communities were never informed on the impacts of the project to their land and never had a chance to provide input in the resettlement deal (Adler, 2012; Herbertson, 2012).

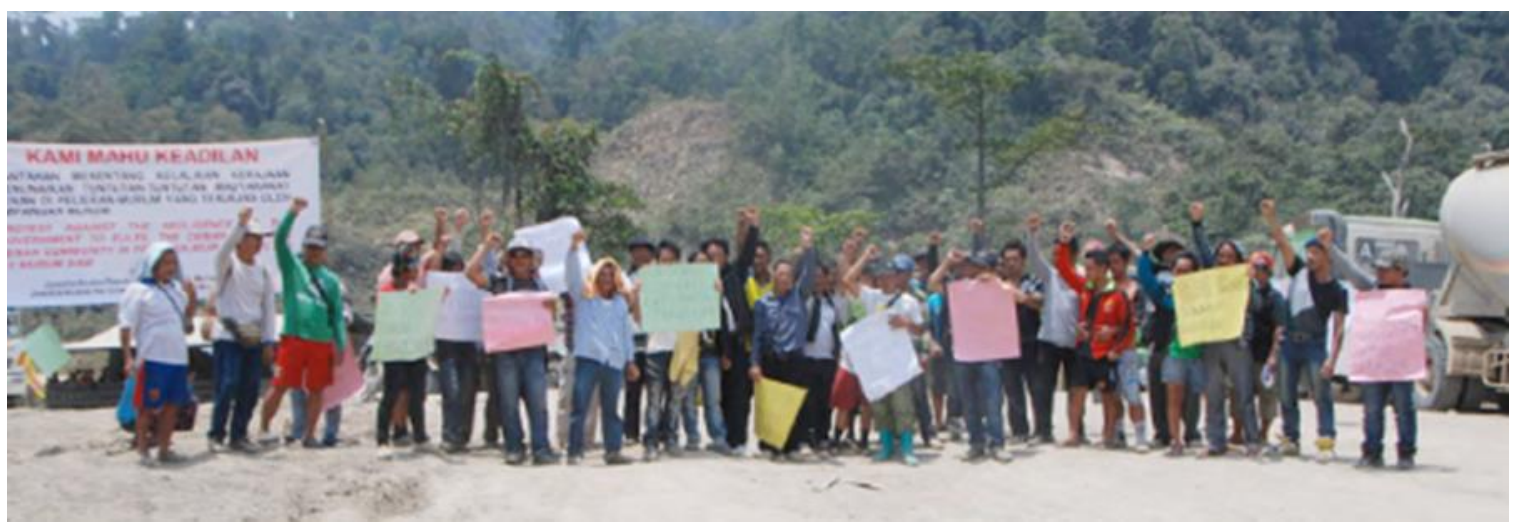

Figure 2: Indigenous Blockade for Murum Dam

Source: Fonds, B. (2012). Slow Down The River-How Sarawak Dam Plans Compromise the Future of Malaysia's Indigenous Peoples. from www.stop-corruption-dams.com

\subsection{The Baram Dam}

Soon after the Murum Dam, Baram Dam was the next dam to be built in Sarawak. The construction of Baram Dam is said to submerge 159 square miles which is equivalent to 412 kilometres of rainforest and affecting over 20,000 indigenous people living near the Baram river (Ling, 2013). In the attempts to conduct the EIA report, the consultants hired by the project proponent engaged in coercive tactics which include closed-door meeting with selected individuals, verbal threats on elders, pressuring youth with monetary incentives and prematurely acquiring land without consent (Lee et al., 2014). In consequence, the affected community voiced out their disagreement and started to set up two blockades at the site of the Baram dam in October 2013 (Bardeen, 2016; Fonds, 2012). According to Lee (2014) and Bardeen (2016), the Baram community has chased away the workers that were doing geological studies for the dam and they have established two road blockades the prevent construction, surveying works and logging at the proposed location of the Baram Dam. As a result, the project was stopped for over two years (Bardeen, 2016; Lee et al., 2014). According to Bardeen (2016), the Sarawak Government has officially cancelled the gazette in acquiring land for the dam and returned the lands to its rightful owners in 2016 after five years of resistance from the villagers against the Baram Dam. 


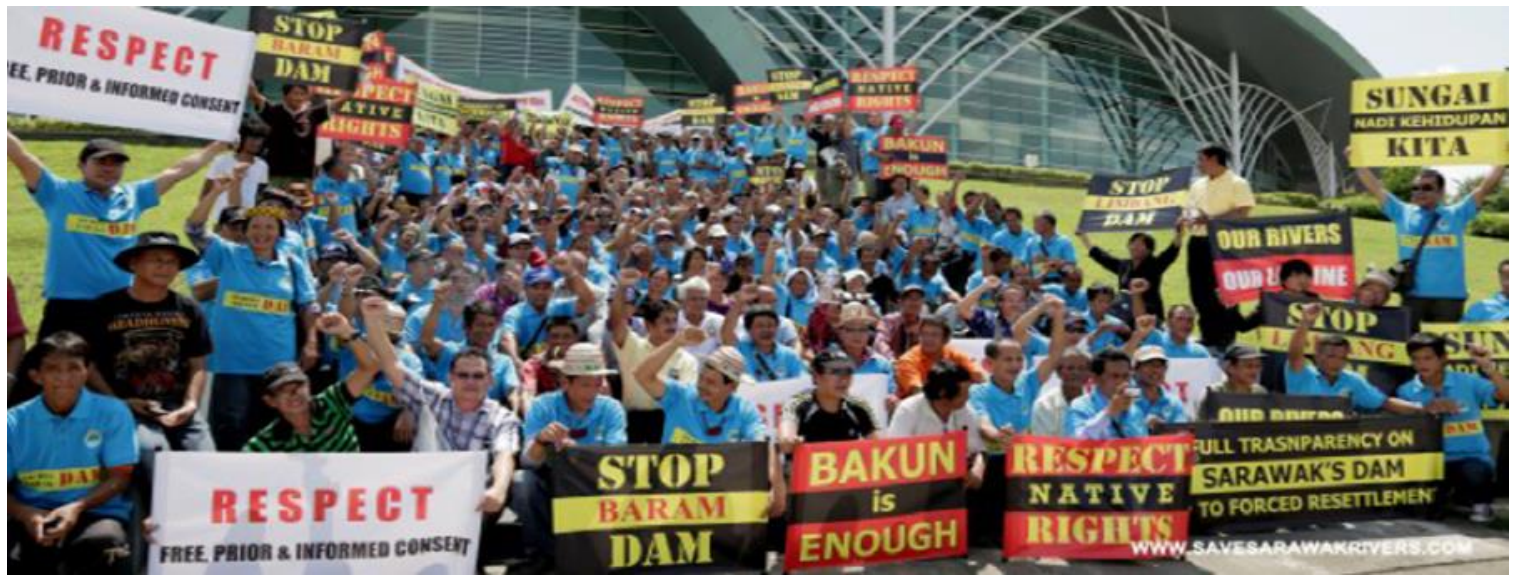

Figure 3: Protest for Baram Dam

Source:. Yoon, R. (2013). Australian Greens join protests against dams in Sarawak. https://asiancorrespondent.com/2013/05/australian-greens-join-protests-against-dams-in-sarawak/

\subsection{The Bauxite Mining}

The bauxite mining in Kuantan, Pahang attracted bad press due to the various negative environmental effects and also negative health impacts to the nearby community. The bauxite mining activities started somewhere in 2014 that were situated in Felda Bukit Goh and Felda Bukit Kuantan where no EIA were submitted for the mining projects (BBC, 2016; Online, 2018). The Pahang State Development Corporation (PKNP) had stated that the EIA was conducted on a huge piece of land (around 3,642 hectares) but until today, no EIA has been submitted to the DOE (Alagesh, 2019).

The mining frenzy was occurred due to China's massive aluminium industry where Malaysia is now the world's top producer of bauxite ore (BBC, 2016; King, 2016). According to BBC (2016), the output of bauxite ore per annum in Malaysia has increased from 200,000 tonnes to nearly 20 million tonnes in 2015. Another reason for the escalated demand for bauxite ore was when Indonesia banned the exports of bauxite ore to China. Thus, causing Indonesian mining companies to look for other bauxite sites, which led them to Kuantan where plentiful bauxite was available (BBC, 2016; King, 2016).

All mining activities were banned in early 2016 after unregulated mining and run-off from unsecured stockpiles which contaminated water sourced in eastern state of Pahang (Malaysiakini, 2019; Online, 2019a). Figure 4 shows the contaminated water in Kuantan due to the bauxite mining. According to Malaysiakini (2019), a moratorium period were imposed in 2016 but the ban was lifted early this year due to strong demand for bauxite. Nonetheless, the Government required the bauxite miners to conduct an EIA on their sites prior to receiving licences to restart their operations (Malaysiakini, 2019).

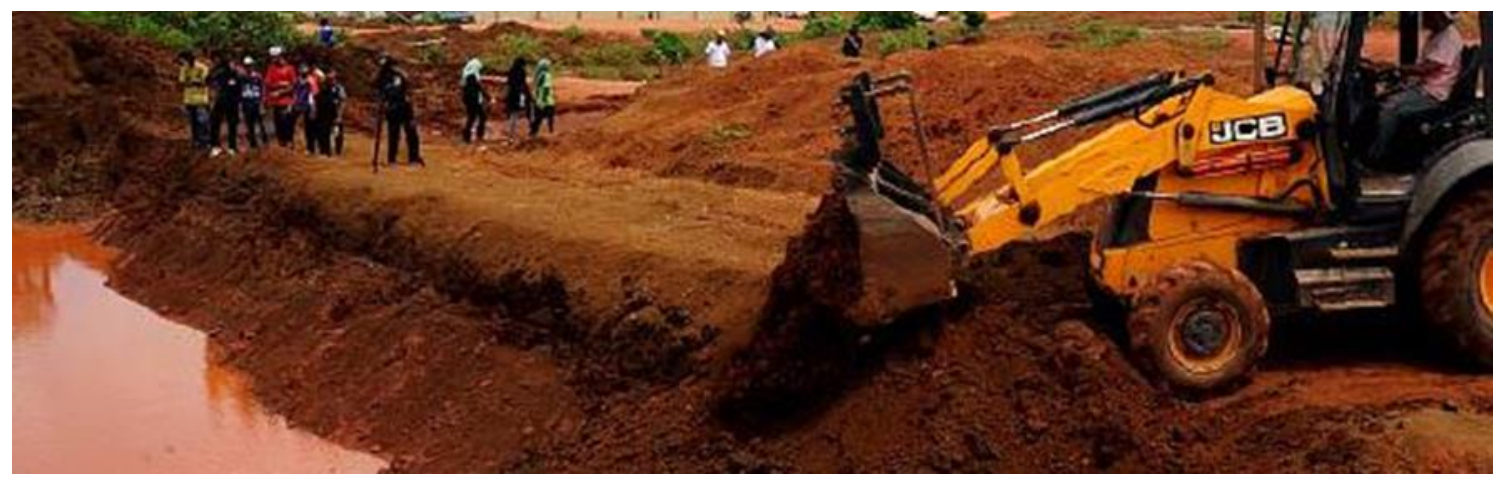

Figure 4: Bauxite Mining in Kuantan

Source: Online, T. S. (Producer). (2019, 23 October 2019). Malaysia to keep bauxite mining on hold amid environmental impact studies. Retrieved from https://www.thestar.com.my/business/businessnews/2019/03/13/malaysia-to-keep-bauxite-mining-on-hold-amid-environmental-impact-studies 


\subsection{The Gold Mining}

The other controversial mining project is the gold mining at Bukit Koman, Raub, Pahang where the Raub Australian Gold Mine (RAGM) used cyanide in their mining operations. Bukit Koman is a small village in Raub where it is situated in the middle of the gold mining area (Tan, 2012). It all started in 1997 where the Preliminary Environmental Impact Assessment (PEIA) were approved by the DOE (Ming, 2012a, 2012b). The goldmine started its operation in 2007 and triggered an outcry from Bukit Koman villagers that were having health problems such as skin rashes, nausea, vomiting, throat irritation and shortness of breath (Malaysiakini, 2015; Ming, 2012a). The residents of Bukit Koman have filed a petition to object the cyanide use in gold mining in Bukit Koman but no response was received (Ming, 2012b; Tan, 2012).

In early 2008, the residents of Bukit Koman appointed a cyanide mining expert from US to visit, evaluate and prepare an expert report on the gold mining by RAGM (Ming, 2012a;2012b). In March 2008, the residents of Bukit Koman filed a law suit to challenge the Director General of DOE for approving the PEIA submitted by RAGM (Ming, 2012b; Tan, 2012). The law suit that was submitted to the High Court was rejected in the following year because the public can only challenge the PEIA within 40 days after the approval and the DOE do not have the right to request a Detailed EIA from the RAGM (Ming, 2012b; Tan, 2012). The residents decided to appeal to the Federal Court in 2011 and finally the Federal court forced RAGM to conduct Detailed EIA (Ming, 2012b; Tan, 2012). Thus, the RAGM is no longer operating and was instructed to rehabilitate the gold mine site. Figure 5 shows the protest made by the residents of Bukit Koman.

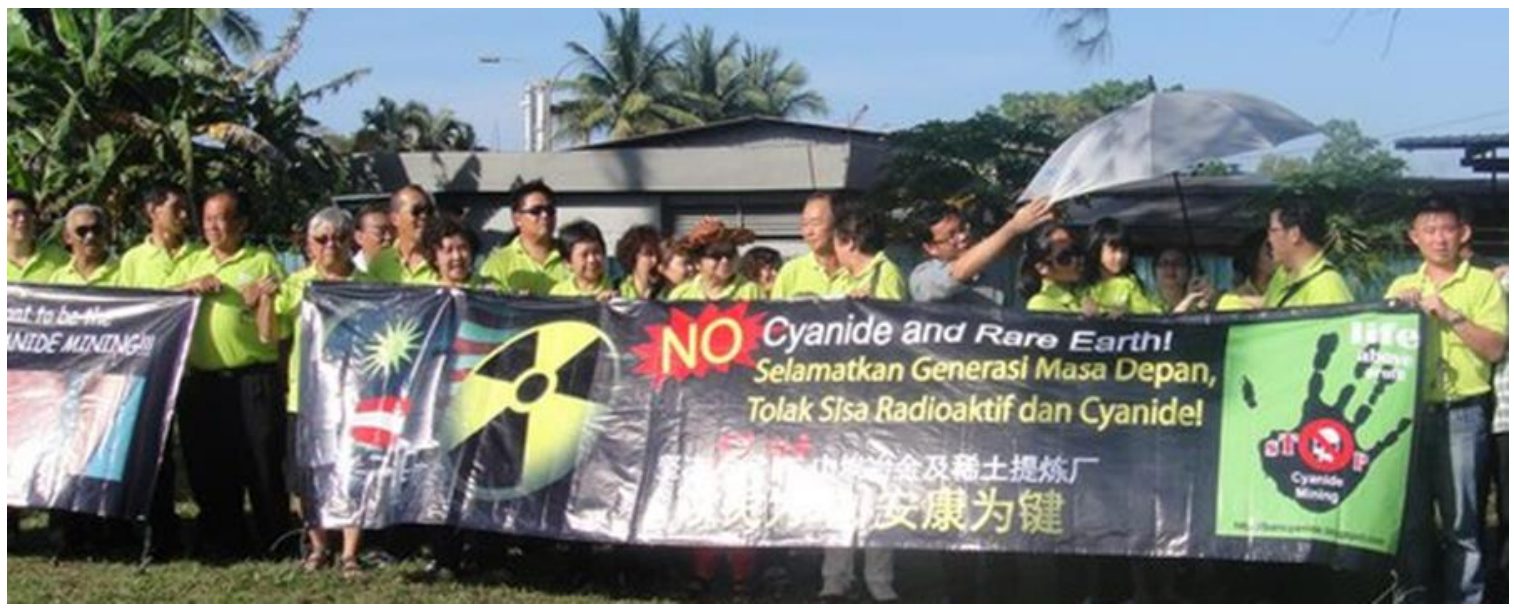

Figure 5: Protest for gold mining in Bukit Koman

Source: Daily, P. (2011). Penduduk Bukit Koman Akan Ketahui Keputusan Cabar Ketua Pengarah JAS Luluskan Laporan EIA Syarikat Emas 'Raub Australian Gold Mining' Esok. from http://pahangdaily.blogspot.com/2011/08/isu-cynide-penduduk-bukit-koman-raub.html

\subsection{The Sturgeon Farming}

Another project that made the headlines was the sturgeon farming project in Kuala Tahan. The sturgeon farming project utilised around 20 hectares of land in Tebung River in Kuala Tahan which is located approximately 2 kilometres upstream of the Tembeling River. The sturgeon farming is a joint-venture project, between Felda Investment Corporation and MMC Hassed Co Ltd of South Korea to rear sturgeon fish to harvest their roe, which is turned into a luxury delicacy called caviar (Online, 2014, 2017).

The sturgeon farming project received strong objections in 2013 when the site was to be built on the border of Taman Negara (Online, 2017). According to Hussain (2014), the project was objected due to the sturgeon fish being a predatory fish, which will cause harm and increase chances of extinction to the other fish species if any of the sturgeon fish enters the Tembeling River. Moreover, there are about 800 residents whose source of income are through eco-tourism and the implementation of this project will affect their income and also disrupts the natural ecosystem in Kuala Tahan (Hussain, 2014). 
The objection on the sturgeon farming project aggravated when the Detailed EIA submitted was rejected and the project was carried out regardless (Online, 2014, 2017). Figure 6 show the protest from the local residents against the sturgeon farming project in Kuala Tahan. In 2014, Jerantut member of parliament, Datuk Ahmad Nazlan Idris instructed a stop work order for the site after it was found to have flouted the regulations (NST, 2017). Datuk Ahmad Nazlan Idris stated that Taman Negara is an eco-tourism destination and by that, the ecotourism value had to be protected (Online, 2014). After two years, it was reported that the sturgeon farming project would be relocated after failing to get the Detailed EIA approval (NST, 2017).

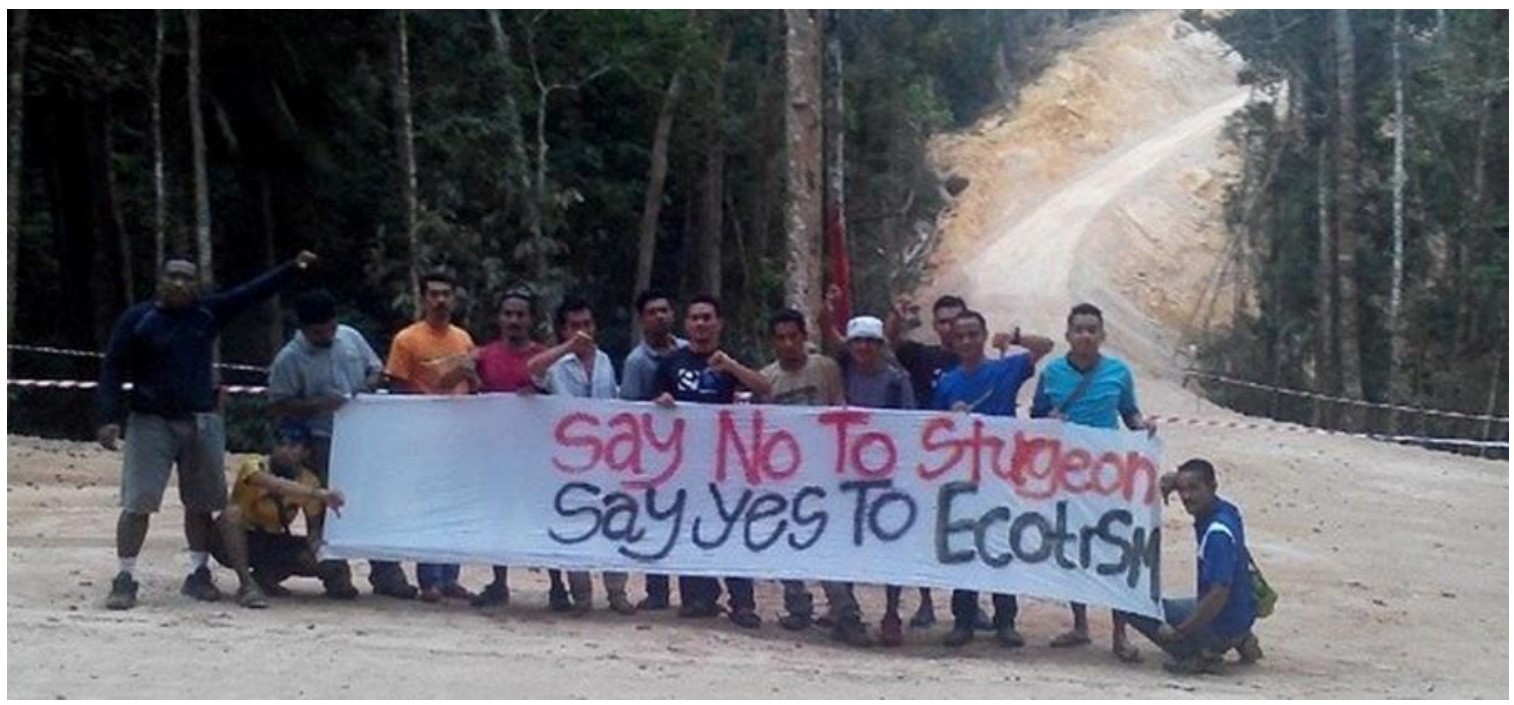

Figure 6: Protest against the sturgeon farming project in Kuala Tahan

Source: Hussain, N. A. M. (2014). Projek Ikan Sturgeon Dihentikan. Mstar. Retrieved from https://www.mstar.com.my/lokal/semasa/2014/08/15/projek-ikan-sturgeon?la=en

\subsection{The Lynas Plant}

The last project is definitely not the least as it has become one of the largest environmental issues in Malaysia. The infamous and very controversial project is the Lynas plant project in Kuantan where it is managed by the Australian company, Lynas Corporation Limited. The Lynas Corp managed the refinery where it processed rare earth ore, which were mined at Mount Weld in Western Australia and shipped to the port of Kuantan since 2012 (Harvey, 2014; Phua \& Velu, 2012). This project created a massive controversy as it is feared to impose major negative health, environmental and economic impacts once the plant started operating (Phua \& Velu, 2012).

Phua \& Velu (2012) and Helwig (2014) stated that the public mistrust on the project is linked to Mitsubishi rare earths plant in Bukit Merah in 1980s that was shut down in 1990s after apparent negative health effects and environmental radiactive contamination was detected. Phua \& Velu (2012) stated that the protests to shut down Lynas was actively carried out in early 2011. The refining plant was given a temporary operating license by the Government which is valid for two years for only submitting the Preliminary EIA (PEIA) which does not require public participation (Phua, 2014).

Soon after that, the public amplified the campaigns and protests, which accumulated more than 1.2 million people who signed the petition urging the Lynas plant to be shut down and the temporary license to be revoked (Harvey, 2014; International, 2014). The project was greatly criticized due to the lack of effective community consultations, restricted access to a flawed PEIA and operating without a permanent waste disposal facility despite highly radioactive waste (Helwig, 2014; International, 2014; Phua \& Velu, 2012). Nonetheless, the Lynas plant is still operating and the temporary operating license has been extended for another six months, starting September 2019 (Online, 2019b). In spite of the fact that the temporary operating license for Lynas has been extended, the Star Online (2019b) reported that the Government has imposed stricter conditions pertaining to waste handling. 


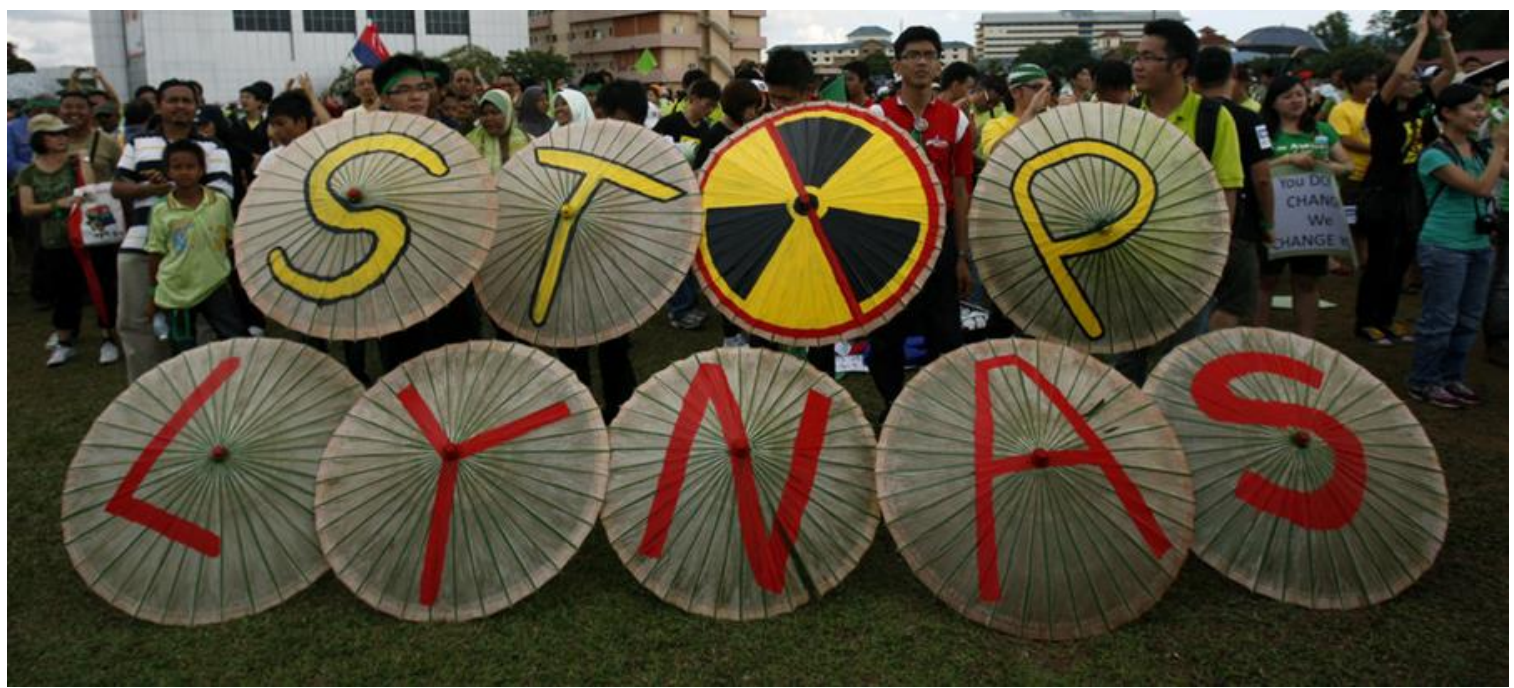

Figure 7: Protest for Lynas

Source: Gooch, L. (2012). Environmental Protest Becomes Rallying Point in Malaysia. The New York Times.

Retrieved from https://www.nytimes.com/2012/06/19/business/global/green-movement-takes-root-inmalaysia.html

\section{METHODOLOGY}

A qualitative approach were utilised in this paper where an extensive review was made on the existing literature on the related environmental cases in Malaysia. The literature review were carried out in the first stage of data collection for this research. The literature review is carried out to understand the background of the research which comprised of environmental cases resulted from the lack of public participation. This stage reviews the cases that were resulted from flawed EIA to provide an understanding of the situation of ineffective practice of public participation for EIA in Malaysia. This literature review provides a factual evidence to support the research as a whole. This research utilised a mixture of quantitative and qualitative methods for data collection which includes the qualitative method in the literature review. This review of literature served as a background study to the research to further improve the practice of public participation for EIA in Malaysia.

\section{RESULTS AND DISCUSSIONS}

Effective public participation for EIA allows transparency in communications between entities and instil responsibilities in parties involves in developing a project. Thus, rendering a more positive decision that fulfil people's needs and protect the environment. The negative effect of poor public publication is evident as seen in the seven environmental cases discussed in this paper.

The seven cases can be classified in terms of the results of the cases that were driven by public protests. There are four cases that resulted to positive outcomes whereby the projects were ceased or relocated due to the public's objections and protests. The first case is the case of the Baram Dam where the issue in this case was the EIA conducted for this project was conducted using coercive tactics to the local communities. There was a lack of effective public participation where the local communities were forced to support the planning of the project. The second project is the bauxite mining in Kuantan, Pahang. The issue on this project was the Pahang State Development Corporation (PKNP) had claimed that an EIA was conducted on a huge piece of land (around 3,642 hectares) and was submitted to the DOE. The claim was justified when no EIA were recorded that was submitted to the DOE. Due to the bauxite mining frenzy that was happening in 2016, a moratorium period was imposed in the same year. EIA submission for the mining operation is required upon the end of the moratorium period to restart the mining operations.

Next, the gold mining in Raub, Pahang was the third case that was ceased after much protests from the local communities. A preliminary EIA were submitted and approved without having any public participation. The issue 
escalated when the affected community started to have serious health problems and it sparked the protest to ban the use of cyanide in gold mining. After operating for about 4 years, the Federal Court have forced the company to conduct a Detailed EIA and the company decided to cease its operation. Lastly, the case of the sturgeon farming in Kuala Tahan had to be relocated after a series of protests by the local community. The main issue with this case was the Detailed EIA that was submitted for this project was rejected by the DOE but the project was still in operation after the rejected Detailed EIA. The sturgeon farming project imposed a serious threat to the eco-tourism near to Taman Negara. In 2013, a stop work order was issued for the project and the project was relocated after two years. From the four cases, it can be concluded that the public protests and environmental campaigns have effects to the project that cause the project to halt or cease.

In contrary, there are three out of the seven cases that proceeded despite the public protests and controversy. The first case is the infamous case of Bakun Dam which was filled with controversy. The Bakun Dam project was slammed for conducting an EIA report after the construction of the dam has begun. This EIA report that was conducted was seriously flawed as it was severely lack of public participation and was also not available for public viewing. The EIA report for the Bakun Dam was classified as confidential document and the public viewing of such documents were denied. Nevertheless, after much controversy and public protests, the Bakun Dam proceeded and it was completed in 2011. The Bakun Dam is a product of public scrutiny for almost 25 years which have degraded the principle of free, prior and informed consent.

The next project is the Murum Dam which was the second dam proposed in Sarawak after the Bakun Dam. This project endured the same issue as the Bakun Dam where the EIA for the Murum Dam was conducted after the construction of the dam has begun. Thus, leading to the lack of public participation in the EIA and the public viewing of the EIA documents to be prohibited. However, leaked copies of the resettlement plans for Murum Dam were circulated among the affected communities that lead to a blockade at the Murum Dam site. The blockade managed to cease the construction of the dam for over a month and also has alerted the media on the controversy on the resettlement plans. Due to this predicament, the Government were forced to conduct resettlement negotiations with the affected communities. Nonetheless, the controversy in this case did not manage to stop the construction and the Murum Dam was completed in 2013.

Lastly, the controversial radioactive plant situated in Kuantan, Pahang. The Lynas plant has received a fair share of public scrutiny and media attention since it started operating in 2012. The Lynas project has submitted Preliminary EIA to the DOE and it was approved. The argument started when the fear of serious health problems were related to the plant and how its operation were approved by merely submitting a Preliminary EIA report. The Preliminary EIA report does not require public participation which is one of the big issues related to the operation of the plant. The Lynas plant has amplified environmental campaigns and protest for its operation. After much dispute on ceasing the radioactive plant, the Lynas plant is still in operation until today. Table 1 concluded the issues and the result of each cases chosen for this paper.

Table 1: Issues and Results of Environmental Cases in Malaysia

\begin{tabular}{|c|c|c|c|c|}
\hline $\begin{array}{l}\text { Environmental } \\
\text { Case }\end{array}$ & Location & Year & Issues & Result \\
\hline The Baram Dam & Sarawak & 2013 & $\begin{array}{l}\text { 1. EIA conducted using coercive } \\
\text { tactics. } \\
\text { 2. Lack of public participation. }\end{array}$ & $\begin{array}{l}\text { The Baram Dam was ceased } \\
\text { and the lands were returned to } \\
\text { the villagers. }\end{array}$ \\
\hline $\begin{array}{l}\text { The Bauxite } \\
\text { Mining }\end{array}$ & $\begin{array}{l}\text { Kuantan, } \\
\text { Pahang }\end{array}$ & 2014 & No EIA submitted to the DOE. & $\begin{array}{l}\text { A moratorium period for } \\
\text { bauxite mining imposed in } \\
\text { 2016. EIA were required prior } \\
\text { to restart the mining operations }\end{array}$ \\
\hline $\begin{array}{l}\text { The Gold } \\
\text { Mining }\end{array}$ & $\begin{array}{l}\text { Raub, } \\
\text { Pahang }\end{array}$ & 1997 & $\begin{array}{l}\text { Preliminary EIA were approved } \\
\text { by the DOE, was challenged due } \\
\text { to the use of cyanide. }\end{array}$ & $\begin{array}{l}\text { The gold mine is no longer in } \\
\text { operation. }\end{array}$ \\
\hline $\begin{array}{l}\text { The Sturgeon } \\
\text { Farming }\end{array}$ & $\begin{array}{l}\text { Kuala } \\
\text { Tahan, } \\
\text { Pahang }\end{array}$ & 2013 & $\begin{array}{l}\text { Detailed EIA submitted was } \\
\text { rejected by the DOE but the } \\
\text { project still went on. }\end{array}$ & $\begin{array}{l}\text { The sturgeon farming project } \\
\text { was relocated. }\end{array}$ \\
\hline The Bakun Dam & Sarawak & 1986 & $\begin{array}{l}\text { 1. EIA conducted after the } \\
\text { construction of the dam has } \\
\text { started. }\end{array}$ & $\begin{array}{l}\text { The Bakun Dam was completed } \\
\text { in } 2011 .\end{array}$ \\
\hline
\end{tabular}




\begin{tabular}{|c|l|l|l|l|}
\hline & & $\begin{array}{l}\text { 2. Lack of public participation. } \\
\text { 3. EIA reports were not available } \\
\text { for public viewing. }\end{array}$ & \\
\hline $\begin{array}{c}\text { The Murum } \\
\text { Dam }\end{array}$ & Sarawak & 2008 & $\begin{array}{l}\text { 1. EIA conducted after the } \\
\text { construction of the dam has } \\
\text { started. } \\
\text { 2. Lack of public participation. } \\
\text { 3. EIA reports were not available } \\
\text { for public viewing. }\end{array}$ & $\begin{array}{l}\text { The Murum Dam was } \\
\text { completed in 2013. }\end{array}$ \\
\hline The Lynas Plant & $\begin{array}{c}\text { Kuantan, } \\
\text { Pahang }\end{array}$ & 2012 & $\begin{array}{l}\text { Preliminary EIA were approved } \\
\text { by the DOE which does not } \\
\text { include public participation. }\end{array}$ & $\begin{array}{l}\text { The Lynas plant is still in } \\
\text { operation. }\end{array}$ \\
\hline
\end{tabular}

\section{CONCLUSIONS}

The seven environmental cases discussed exhibit the negative implications of flawed EIA due to the nonexistent EIA or the ineffective public participation administered. Major objections and protests were results of ineffective public participations and ineffective EIAs. The result of these protests have made substantive results which ceased the projects in the cases of the Baram Dam, the bauxite mining in Kuantan, the gold mining in Bukit Koman and the Sturgeon farming in Kuala Tahan. On the other hand, the protests in the cases of Bakun Dam, Murum Dam and Lynas have failed to cease the project but it have proliferated the environmental awareness of the society in Malaysia to be more vigilant on the detrimental effects of a proposed development towards the environment and society.

\section{ACKNOWLEDGEMENT}

The authors would like to express their gratitude for the financial support from University of Malaya (UM) under the Postgraduate Research Grant (PPP), PG055-2015B and MOHE (Minister of Higher Education) under $\mathrm{MyPhD}(\mathrm{MyBrain} 15)$ given to this research

\section{REFERENCES}

Abaza, H., Bisset, R., \& Sadler, B. (2004). Environmental Impact Assessment and Strategic Environmental Assessment: Towards an Integrated Approach (First ed.): United Nations Environment Programme (UNEP).

Achoi, J. (2017). Electricity from Bakun Dam will not be sold to Peninsular Malaysia-CM. Retrieved March 5, 2020, from https://www.theborneopost.com/2017/09/21/electricity-from-bakun-dam-will-not-be-sold-topeninsular-malaysia-cm/

Adler, S. (2012). Malaysia's Murum Dam Sets Poor Precedents for Best Practice. Retrieved October 31, 2019, from https://www.internationalrivers.org/blogs/298/malaysia\%E2\%80\%99s-murum-dam-sets-poorprecedents-for-best-practice

Ahmad, M. H., Seow, T. W., \& Dalimin, M. N. (2013, 23 December 2013). Public Participation on Detailed Environment Impact Assessment in Malaysia. Paper presented at the 1st FPTP Postgraduate Seminar 2013, Fakulti Pengurusan Teknologi dan Perniagaan, UTHM.

Aiyeola, A., Abdullah, R., Shamsudeen, N., \& Ibrahim, Z. Z. (2014). Examine the level of Public Participation in Environmental Malaysia Impact Assessment Process: A case of MRT Project in Malaysia. IOSR Journal of Environmental Science, Toxicology and Food Technology (IOSR-JESTFT), 8(6), 8-12.

Alagesh, T. N. (2019). Uncertainty looms over bauxite mining activities due to absence of EIA and SOP. New Straits Times. Retrieved from https://www.nst.com.my/news/nation/2019/03/465022/uncertainty-loomsover-bauxite-mining-activities-due-absence-eia-and-sop 
Alam, S. (2014). Public Participation in the Enforcement of Environmental Laws: Issues and challenges in the light of the legal and regulatory framework with special reference to EIAs in Malaysia. Bangladesh Research Foundation Journal, 3(1), 87-101.

Allison, T. (2000). Malaysia's Bakun project: Build and be damned. Retrieved from Asia Times Online: http://www.atimes.com/reports/BJ28Ai01.html

Bardeen, S. (2016). Baram Dam Stopped! A Victory for Indigenous Rights. Retrieved from https://www.internationalrivers.org/blogs/433-18

Bastmeijer, K., \& Koivurova, T. (Eds.). (2008). Theory and Practice of Transboundary Environmental Impact Assessment. Netherlands: Martinus Nijhoff Publishers.

Bataneih, R. H. (2007). The Effectiveness of the Environmental Impact Assessment (EIA) follow-up with regard to biodiversity conservation in Azerbaijan. Management of Environmental Quality: An International Journal, 18(5), 591-596.

BBC (Producer). (2016, 23 October 2019). Bauxite in Malaysia: The environmental cost of mining. Retrieved from https://www.bbc.com/news/world-asia-35340528

Bhatt, R. P., \& Khanal, S. N. (2009). Environmental Impact Assessment System in Nepal - An Overview of Policy, Legal Instruments and Process. Kathmandu University Journal of Science, Engineering and Technology, 5(2), 160-170.

Briffet, C. (1999). Environmental Impact Assessment in Southeast Asia: fact or fiction? GeoJournal, 49(3), 333338.

Bruch, C., Nakayama, M., Troell, J., Goldman, L., \& Mrema, E. M. (2007). Assessing the Assessments: Improving Methodologies for Impact Assessment in Transboundary Watercourses. International Journal of Water Resources Development, 23(3), 391-410.

Coşkun, A. A., \& Turker, O. (2011). Analysis of Environmental Impact Assessment (EIA). Environmental Monitoring and Assessment, 175, 213-226.

Daily, P. (2011). Penduduk Bukit Koman Akan Ketahui Keputusan Cabar Ketua Pengarah JAS Luluskan Laporan EIA Syarikat Emas 'Raub Australian Gold Mining' Esok. Retrieved from http://pahangdaily.blogspot.com/2011/08/isu-cynide-penduduk-bukit-koman-raub.html

Dian, A. M., \& Abdullah, N. C. (2013). Public Participation in Heritage Sites Conservation in Malaysia: Issues and challenges. Procedia - Social and Behavioral Sciences, 101, 248 - 255.

Erikstad, L., Lindblom, I., Jerpasen, G., Hanssen, M., Bekkby, T., \& Stabbetorp, O. (2008). Environmental value assessment in a multidisiplinary EIA setting. Environmental Impact Assesment Review, 28, 131-143.

Fonds, B. M. (2012). Slow Down The River-How Sarawak Dam Plans Compromise the Future of Malaysia's Indigenous Peoples. Retrieved from www.stop-corruption-dams.com

Gillespie, A. (2008). Environmental Impact Assessment in International Law. Review of European Community \& International Environmental Law, 17(2), 221-233.

Glasson, J., Therivel, R., \& Chadwi, A. (Eds.). (2005). Introduction to Environmental Impact Assessment (3rd ed.). Oxfordshire, UK: Routledge.

Glucker, A. N., Driessen, P. P. J., Kolhoff, A., \& Runhaar, H. A. C. (2013). Public participation in environmental impact assessment: why, who and how? Environmental Impact Assessment Review, 43, 104-111. 
Hartley, N., \& Wood, C. (2005). Public Participation in environmental impact assessment - implement the Aarhus Convention. Environmental Impact Assessment Review, 25, 319-340.

Harvey, G. (2014). Arrests at Malaysian Rare Earths Refinery Protests: Locals and activists fear the refinery, operated by an Australian company, will generate radioactive waste. Retrieved from The Diplomat https://thediplomat.com/2014/06/arrests-at-malaysian-rare-earths-refinery-protests/

Hasan, M. A., Nahiduzzaman, K. M., \& Aldosary, A. S. (2018). Public participation in EIA: A comparative study of the projects run by government and non-governmental organizations. Environment Impact Assessment Review, 72, 12-24.

He, G., Zhang, L., \& Lu, Y. (2009). Environmental Impact Assessment and Environmental Audit in Large-Scale Public Infrastructure Construction: The Case of the Qinghai-Tibet Railway. Environmental Management, 44, 579-589.

Helwig, N. M. (2014). Lynas Corporation's Rares Earths Refinery in Malaysia -Vying for a License to Operate Amid Cries to Shut Down. Retrieved from www.stoplynas.org

Herbertson, K. (2012). Malaysia: What to Do When Indigenous Groups Blockade Your Dam.

Hussain, N. A. M. (2014). Projek Ikan Sturgeon Dihentikan. Mstar. Retrieved from https://www.mstar.com.my/lokal/semasa/2014/08/15/projek-ikan-sturgeon?la=en

International, F. o. t. E. (2014). Environmental activism under threat in Malaysia. Retrieved 23 October 2019 from https://www.foei.org/press_releases/archive-by-subject/resisting-mining-oil-gaspress/environmental-activism-under-threat-in-malaysia

Kanniah, R. (2000). Public Participation in the Environmental Impact Assessment Process in Malaysia. Malayan Law Journal Articles, 3, 1-16.

Khalid, K. A. T. (2007). Global Networks: Issues and Tactics in the Bakun Dam Project. Jebat: Malaysian Journal of History, Politics and Strategic Studies, 34, 1-16.

King, E. (2016). Sustainable Mining: A Global Problem Demands a Global Situation. Retrieved from https://intpolicydigest.org/2016/05/03/sustainableminingaglobalproblemdemandsaglobalsolution/

Kolhoff, A. J., Driessen, P. P. J., \& Runhaar, H. A. C. (2013). An Analysis Framework for Characterizing and Explaining Development of EIA Legislation in Developing Countries- Illustrated for Georgia, Ghana and Yemen. Environmental Impact Assessment Review, 38, 1-15.

Lawrence, D. P. (2003). Environmental Impact Assessment: Practical Solutions to Recurrent Problems. New Jersey, USA: John Wiley \& Sons, Inc.

Lee, N., \& George, C. (Eds.). (2000). Environmental Assessment in Developing and Transitional Countries: Principles, Methods and Practice. West Sussex, UK: John Wiley \& Sons, Inc.

Lee, W. C., Viswanathan, K. K., \& Ali, J. (2014). Compensation policy in a large development project: the case of the Bakun hydroelectric dam. International Journal of Water Resources Development, 1-9.

Ling, G. P. (2013). Megadam Project Galvanizes Native Opposition in Malaysia. Retrieved from https://www.nationalgeographic.com/news/energy/2013/02/130227-malaysia-score-megadamproject.html

Maidin, A. J. (2011). Access to Public Participation in the Land Planning and Environmental Decision Making Process in Malaysia. International Journal of Humanities and Social Sciences, 1(3), 148-164. 
Malaysiakini. (2015). RAGM to resume mining operation. Malaysiakini. Retrieved from https://www.malaysiakini.com/news/306550

Malaysiakini. (2019). Malaysia firms up on bauxite mining, export operating procedures. Malaysiakini. Retrieved from https://www.malaysiakini.com/news/490743

Marara, M., Okello, N., Kuhanwa, Z., Douven, W., Beevers, L., \& Leentvaar, J. (2011). The importance of context in delivering effective EIA: Case studies from East Africa. Environment Impact Assessment Review, 31(286-296).

Ming, S. (2012a). Bukit Koman: 10 Reasons Why We Protest Against the Use of Cyanide in the Gold Mine Operation. $1-4$ Retrieved from http://www.loyarburok.com/2012/08/30/bukitkoman10reasonsprotestcyanidegoldoperation/

Ming, S. (2012b). Bukit Koman: Ban Cyanide in Gold Mining. Retrieved from https://www.loyarburok.com/2012/08/28/bukit-koman-ban-cyanide-gold-mining/

Momtaz, S., \& Gladstone, W. (2008). Ban on commercial fishing in the estuarine waters of New South Wales, Australia: Community consultation and social impacts. Environment Impact Assessment Review, 28(2), 214-225.

Morrison-Saunders, A., \& Early, G. (2008). What is necessary to ensure natural justice in environmental impact assessment decisionmaking? Impact Assessment and Project Appraisal, 26(1), 29-42.

Nadeem, O., \& Hameed, R. (2008). Evaluation of environmental impact assessment in Pakistan. Environment Impact Assessment Review, 28(8), 562-571.

NST. (2017). Sturgeon-farming project: Residents' suspicions proven right. Retrieved from https://www.nst.com.my/news/2017/01/207429/sturgeon-farming-project-residents-suspicions-provenright

Online, T. S. (2014). RM120mil project found to have flouted regulations and procedures. Retrieved from https://www.thestar.com.my/news/nation/2014/10/01/sturgeon-fish-farm-on-hold-rm120mil-projectfound-to-have-flouted-regulations-and-procedures

Online, T. S. (2017). Strong objections to sturgeon farming project.

Online, T. S. (2019b). Lynas gets six more months. https://www.thestar.com.my/news/nation/2019/08/16/lynasgets-six-more-months

Online, T. S. (2018, 23 October 2019). 'Bauxite mining go-ahead depends on EIA report'. Retrieved from https://www.thestar.com.my/news/nation/2018/02/28/bauxite-mining-goahead-depends-on-eia-report

Online, T. S. (2019a, 23 October 2019). Malaysia to keep bauxite mining on hold amid environmental impact studies. Retrieved from https://www.thestar.com.my/business/business-news/2019/03/13/malaysia-tokeep-bauxite-mining-on-hold-amid-environmental-impact-studies

Peche, R., \& Rodríguez, E. (2009). Environmental impact assessment procedure: A new approach based on fuzzy logic. Environmental Impact Assessment Review, 29, 275-283.

Phillips, J. (2011). The conceptual development of geocybernetic relationship between sustainable development and Environment Impact Assessment Applied Geography, 31, 969-979.

Phua, K.-L. (2014). Seven reasons why Lynas shouldn't be granted a permanent operating licence. Retrieved from https://anilnetto.com/economy/development-issues/7-reasons-lynas-granted-permanent-operating-licence/ 
Phua, K.-L., \& Velu, S. S. (2012). Lynas Corporation's Rare Earth Extraction Plant in Gebeng, Malaysia: A Case Report on the Ongoing Saga of People Power versus State-Backed Corporate Power. Journal of Environmental Engineering \& Ecological Science, 1, 1-5.

Pölönen, I., Hokkanen, P., \& Jalava, K. (2011). The Effectiveness of the Finnish EIA system- What works, what doesn't, and what could be improved? Environmental Impact Assessment Review, 31, 120-128.

Sadler, B. (1996). Environmental Assessment in A Changing World: Evaluating Practice to Improve Performance International Study of the Effectiveness of Environmental Assessment: Final Report (pp. 1-263): Canadian Environmental Assessment Agency \& International Association for Impact Assessment.

Salomons, G. H., \& Hoberg, G. (2014). Setting Boundaries of Participation in Environmental Impact Assessment. Environmental Impact Assessment Review, 46, 69-75.

Siciliano, G., Urban, F., Tan-Mullins, M., \& Mohan, G. (2018). Large dams, energy justice and the divergence between international, national and local developmental needs and priorities in the global South. Energy Research \& Social Science, 1-11.

Sovacool, B. K., \& Bulan, L. C. (2011). Behind an ambitious megaproject in Asia: The history and implications of the Bakun hydroelectric dam in Borneo. Energy Policy, 39, 4842-4859.

Stærdahl, J., Schroll, H., Zakaria, Z., Abdullah, M., Dewar, N., \& Panich, N. (2004). Environmental Impact Assessment in Malaysia, South Africa, Thailand and Denmark: Background, layout, context, public participation and environmental scope. The Journal of Transdisciplinary Environmental Studies, 3(1), 118 .

Swain, A., \& Chee, A. M. (2004, 26-27 February). Political Structure and 'Dam' Conflicts: Comparing Cases in Southeast Asia. Paper presented at the Proceedings of the Workshop on Water and Politics: Understanding the Role of Politics in Water Management, Marseille.

Tan, T. K. (2012). Poisoned Gold. Retrieved from https://www.therocket.com.my/en/poisoned-gd/

Tigawuve, C. G. (2012). Environmental Assessment through Comprehensive Studies and Review Panel Process Options under the Canadian Environmental Assessment Act: A Comparative Review of Public Influence in the EA Process. (Master of Laws), Dalhousie University, Halifax, Nova Scotia.

Wood, G. (2000). Is what you see what you get? Post-development auditing of methods used for predicting the zone of visual influence in EIA. Environmental Impact Assessment Review, 20, 537-556.

Yong, C. (2011). Revisiting the Bakun dam controversy. Retrieved from https://hornbillunleashed.wordpress.com/2011/01/17/13703/

Yoon, R. D. R. (2013). Australian Greens join protests against dams in Sarawak. Retrieved from https://asiancorrespondent.com/2013/05/australian-greens-join-protests-against-dams-in-sarawak/ 